\title{
Transamination of the $\boldsymbol{N}$-Terminal Residue of Carboxypeptidase
}

\author{
By S. van Heyningen, K. F. Tipton and H. B. F. Dixon \\ Department of Biochemistry, University of Cambridge
}

\section{(Received 23 April 1968)}

The chemical evidence (Coombs, Omote \& Vallee, 1964) that the essential zinc atom of carboxypeptidase $A_{\gamma}$ is bound to the molecule through the $N$-terminal asparagine residue has been contradicted by the results of Ando \& Fujioka (1962) and by X-ray-crystallographic data (Lipscomb et al. 1966; Reeke et al. 1967), which show the $N$-terminal residue of carboxypeptidase $A_{\alpha}$ to be far from the zinc atom. The results reported here confirm that the $\alpha$-amino group of the $N$-terminal asparagine is not essential by showing that the enzyme remains fully active after transamination.

Dixon \& Moret (1964) showed that the $N$-terminal residue of a protein can be transaminated into an $\alpha$-oxoacyl residue. The best conditions for this (Dixon, 1967) are mild enough for the rest of the protein not to be greatly affected (van Heyningen \& Dixon, 1967). The reaction appears specific for $\alpha$-amino groups; the $\epsilon$-amino groups of lysine residues are not transaminated, probably because a neighbouring peptide carbonyl is necessary to stabilize the reaction intermediate. The $\alpha$-oxoacyl residue can be selectively cleaved from the rest of the molecule by treatment with bifunctional nucleophiles such as o-phenylenediamine (Dixon \& Moret, 1964; van Heyningen \& Dixon, 1967).

The transamination was carried out in a strong acetate buffer (in which carboxypeptidase is completely soluble) as high base concentrations are needed to catalyse the reaction (Dixon, 1967). The pH was about $5 \cdot 4$, which should be low enough for the binding of the zinc atom to be comparatively weak (Vallee, Rupley, Coombs \& Neurath, 1960), so that an amino group bound to it might be available for reaction. Reaction was allowed to proceed for $26 \mathrm{hr}$. as the dissociation of zinc is rather slow; results with other proteins show transamination itself to be complete in $20 \mathrm{~min}$. or so at room temperature. Carboxypeptidase (Calbiochem lot no. 72912$)(0.55 \mathrm{mg} . / \mathrm{ml}$.) was incubated at $1^{\circ}$ for $26 \mathrm{hr}$. in a solution containing $2 \mathrm{M}$-sodium acetate, $0.4 \mathrm{M}$-acetic acid, $0.1 \mathrm{M}$-sodium glyoxylate and $5 \mathrm{~mm}-\mathrm{CuSO}_{4}$. Controls, in which one or more of the reagents were omitted, were incubated under the same conditions. The solutions were then dialysed for $48 \mathrm{hr}$, at $3^{\circ}$ against $\mathrm{M}-\mathrm{NaCl}, 0 \cdot 1 \mathrm{M}$-tris chloride, $\mathrm{pH} 7 \cdot 0$, and $100 \mu \mathrm{M}-\mathrm{ZnSO}_{4}$ to restore activity to any apoenzyme formed. The solutions were then assayed for esterase activity by measuring the rate of release of $\mathrm{H}^{+}$ions from a solution of 5 mM-hippuryl-DL- $\beta$-phenyl-lactate (in $25 \mathrm{~mm}$ - $\mathrm{LiCl}$ and mM-phosphate buffer, $\mathrm{pH} 7.5$ at $25^{\circ}$; Simpson, Riordan \& Vallee, 1963), and for peptidase activity by measuring the release of ninhydrin-positive material (assayed by the method of Rosen, 1957) from a solution of $10 \mathrm{~mm}$-benzyloxycarbonylglycylL-phenylalanine (in $\mathrm{M}-\mathrm{NaCl}$ and $0.05 \mathrm{M}$-tris chloride, $\mathrm{pH} 7.5$ at $25^{\circ}$; Coleman \& Vallee, 1960). Protein concentrations were estimated from the extinction at $278 \mathrm{~m} \mu$ (Bargetzi, Sampath Kumar, Cox, Walsh $\&$ Neurath, 1963). Table 1 shows that the activities of the transaminated enzyme and controls are the same within about $3 \%$, which is less than the experimental error. Peptidase activity fell off by about $25 \%$ on storage at $1^{\circ}$ for $48 \mathrm{hr}$, but the transaminated enzyme and controls had the same activity at any one time. Thus transamination has not affected the stability.

That the enzyme, incubated under conditions known to bring about transamination of some other proteins (Dixon 1967), had indeed transaminated was shown by two methods. (1) Treatment with dansyl chloride (1-dimethylaminonaphthalene-5-sulphonyl chloride) (Gray \&Hartley, 1963) followed by acid hydrolysis showed $N$-terminal aspartic acid (formed from asparagine) in the controls, but showed no $N$-terminus at all in the transaminated enzyme. All samples showed

Table 1. Activity of carboxypeptidase $A_{\gamma}$ after various incubations

The complete medium was the only system in which transamination occurred. The error for inaccuracy of readings is thought to be $<5 \%$ for the peptidase assay and $<8 \%$ for the esterase assay.

\begin{tabular}{|c|c|c|}
\hline Incubation medium & $\begin{array}{c}\text { Peptidase } \\
\text { activity } \\
\left(\Delta E_{570} / \mathrm{min} . /\right. \\
\text { mg. })\end{array}$ & $\begin{array}{c}\text { Esterase } \\
\text { activity } \\
\text { ( } \mu \text { moles/ } \\
\text { min./mg.) }\end{array}$ \\
\hline Complete medium (see the text) & $0 \cdot 148$ & $45 \cdot 6$ \\
\hline Complete medium less $\mathrm{CuSO}_{4}$ & $0 \cdot 146$ & $46 \cdot 5$ \\
\hline $\begin{array}{l}\text { Complete medium less sodium } \\
\text { glyoxylate }\end{array}$ & $0 \cdot 152$ & $45 \cdot 5$ \\
\hline Complete medium less $\mathrm{CuSO}_{4}$ & $0 \cdot 150$ & $44 \cdot 6$ \\
\hline
\end{tabular}

and sodium glyoxylate 
$O$-dansyl-tyrosine and $N^{\epsilon}$-dansyl-lysine, which are normally formed from residues within peptide chains. (Protein was incubated overnight at room temperature in a solution containing $50 \%$ acetone, $0.25 \mathrm{M}-\mathrm{NaHCO}_{3}, 8 \mathrm{M}$-urea and $10 \mathrm{mg}$. of dansyl chloride/ml.) (2) When the transaminated enzyme was incubated under conditions that bring about the scission of terminal $\alpha$-oxoacyl residues (van Heyningen \& Dixon, 1967), the product had tyrosine as $N$-terminal residue. No tyrosine end group was produced when the native enzyme was incubated under the same conditions. Tyrosine is known to be the second residue in carboxypeptidase $A_{y}$, a form of the enzyme that has $N$-terminal asparagine (Bargetzi et al. 1963). The activities of control and transaminated enzymes were completely destroyed by incubation under these conditions.

The fluorescence spectra (excitation at $289 \mathrm{~m} \mu$ ) of the transaminated and native protein were determined. Addition of $8 \mathrm{M}$-urea to a solution of the native enzyme shifted the maximum from 350 to $356 \mathrm{~m} \mu$ (uncorrected) and increased it by about $35 \%$. On transamination, however, the maximum decreased by about $25 \%$ but did not shift. This shows that transamination has changed the environment of one or more of the tyrosine or tryptophan residues. It is obviously possible that the tyrosine residue adjacent to the $N$-terminus is at least partly responsible.

These experiments show that carboxypeptidase $\mathrm{A}_{\gamma}$ retains its activity when the $N$-terminal residue is transaminated into an $\alpha$-oxoacyl residue.

We thank the Wellcome Trust for a grant.

Ando, T. \& Fujioka, H. (1962). J. Biochem., Tokyo, 52, 363. Bargetzi, J.-P., Sampath Kumar, K. S. V., Cox, D. J., Walsh, K. A. \& Neurath, H. (1963). Biochemistry, 2, 1468. Coleman, J. E. \& Vallee, B. L. (1960). J. biol. Chem. 235, 390. Coombs, T. L., Omote, Y. \& Vallee, B. L. (1964). Biochemistry, 3, 653.

Dixon, H. B. F. (1967). Biochem.J. 103, 38 P.

Dixon, H. B. F. \& Moret, V. (1964). Biochem. J. 94, 463. Gray, W. R. \& Hartley, B. S. (1963). Biochem. J. 89, 59 P. Lipscomb, W. N., Coppola, J. C., Hartsuck, J. A., Ludwig, M. L., Muirhead, H., Searl, J. \& Seitz, T. A. (1966). J. molec. Biol. 19, 423.

Reeke, G. N., Hartsuck, J. A., Ludwig, M. L., Quiocho, F. A., Steitz, T. A. \& Lipscomb, W. N. (1967). Proc. nat. Acad. Sci., Wash., 58, 2220.

Rosen, H. (1957). Arch. Biochem. Biophys. 67, 10.

Simpson, R. T., Riordan, J. F. \& Vallee, B. L. (1963). Biochemistry, 2, 616.

Vallee, B. L., Rupley, J. A., Coombs, T. L. \& Neurath, H. (1960). J. biol. Chem. 235, 64.

van Heyningen, S. \& Dixon, H. B. F. (1967). Biochem. J. 104, 63 P. 